\title{
Evaluating the Quality of Life and Sleep Habits in Children Aged 8-18 Years with Migraine
}

\section{8-18 Yaș Migren Hastalarında Yașam Kalitesi ve Uyku Alıșkanlıklarının Değerlendirilmesi}

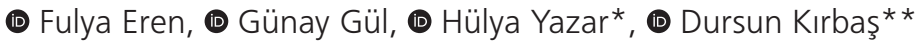

Istanbul Bakırköy Prof. Dr. Mazhar Osman Mental Health and Neurological Diseases Training and Research Hospital, Clinic of Neurology, Istanbul, Turkey *Taksim Training and Research Hospital, Clinic of Neurology, Istanbul, Turkey

**Medical Park Hospital, Clinic of Neurology, Istanbul, Turkey

\begin{abstract}
Objective: Migraine is the most common primary headache among the paediatric population. The frequency of the condition causes a negative effect on children and parents, affecting the quality of life. Migraine and other primary headaches may result in sleep interruption, insomnia, hypersomnia and daytime sleeping. In this study, the quality of life and sleep disorders of children aged 8-18 years with migraine were assessed and compared with a healthy cohort.

Materials and Methods: This study included 43 children or adolescents aged 8-18 years with acute migraine attacks, diagnosed according to the International Headache Society criteria. Parents completed "the children's sleep habits questionnaire" and "pediatric quality of life inventory" tests. The control group included 48 children and adolescents without headache and a diagnosis of migraine. The two groups were compared to assess the negative effects of migraine on children.

Results: The mean ages of the patient (15 boys and 28 girls) and control groups ( 25 boys and 23 girls) were $13.81 \pm 2.78$ and $12.56 \pm 3.5$ years, respectively. The physical health total score $(p=0.000)$, emotional functioning score $(p=0.019)$, school functioning score $(p<0.000)$ psychosocial health total score $(p<0.000)$ and the total scale score $(p<0.000)$ were significantly lower in the patient group. No significant difference was noted in the social functioning score $(p=0.383)$. Additionally, the groups did not differ significantly in terms of sleep behaviour $(p>0.05)$.

Conclusion: The results of this study were similar to those of previous studies, with the exception of decreased social functioning score of the pediatric quality of life inventory. These results substantiate the importance of administering appropriate treatment for pain control in children and adolescents. Specialists and parents should be aware of the potential social problems resulting from migraines.
\end{abstract}

Keywords: Paediatric migraine, quality of life, sleep disorders
Öz

Amaç: Migren, pediyatrik baş ağııları arasında en sık görülen birincil baş ağrısıdır. Sık görülmesi nedeniyle çocuklar ve ebeveynler üzerinde olumsuz etkiye neden olmakta, ayrıca yaşam kalitesini olumsuz etkilemektedir. Migren ve diğer birincil baş ağrıları uyku kesintisine, uykusuzluğa, aşırı uyuma ve gündüz uyumasına neden olabilir. Bu çalışmada, migren tanısı alan 8-18 yaş arası çocuklarda eşlik eden uyku bozukluklarını ortaya çıkarmak ve yaşam kalitesini değerlendirmek amaçlanmıştır.

Gereç ve Yöntem: Uluslararası baş ağrısı sınıflaması kriterlerine göre aurasız migren tanısı ile takip edilen, sadece atak tedavisi alan 8-18 yaş arası 43 çocuk veya ergen çalışmaya dahil edildi. Kontrol grubu baş ağrısı olmayan 48 çocuk ve adölesandan oluşturuldu. Hasta ve kontrol grubu ebeveynlerine "çocuklar için uyku davranışları anketi" ve "pediyatrik yaşam kalitesi envanteri" testleri uygulandı.

Bulgular: Hasta grubunun (15 erkek, 28 kadın) yaş ortalaması 13,81 $\pm 2,78$ idi. Kontrol grubunun (25 erkek, 23 kadın) yas ortalaması $12,56 \pm 3,5$ idi. Fiziksel sağlık toplam puanı $(p=0,000)$, duygusal işlevsellik, okul işlevselliği $(p<0,000)$, psikososyal sağlık toplam puanı $(p<0,000)$, toplam puan kontrol grubuna göre istatistiksel olarak daha düşüktü. Sosyal işlevsellik puanında $(p=0,383)$ anlamlı bir fark yoktu. Uyku davranışında da gruplar arasında anlamlı bir fark bulunmadı $(p>0,05)$.

Sonuç: $\mathrm{Bu}$ çalışmada, pediyatrik yaşam kalitesi envanterinin sosyal işlevsellik puanlarındaki azalma dışında, sonuçlar literatürdeki çalışmalarla benzerdir. Bu sonuç, migren tanısının doğru olmasının, çocuk ve ergenlerde ağrı kontrolü için uygun tedavinin uygulanmasının önemini göstermektedir. Uzmanlar ve ebeveynler olası sosyal sorunlar açısından dikkatli olmalıdır.

Anahtar Kelimeler: Pediyatrik migren, yaşam kalitesi, uyku bozuklukları

Address for Correspondence/Yazışma Adresi: Assoc. Prof. Fulya Eren, İstanbul Bakırköy Prof. Dr. Mazhar Osman Mental Health and Neurological Diseases Training and Research Hospital, Clinic of Neurology, İstanbul, Turkey Phone: +90 5322276160 E-mail: fulyasengul@yahoo.com ORCID-ID: orcid.org/0000-0001-9787-7551 Received/Geliş Tarihi: 31.01.2021 Accepted/Kabul Tarihi: 17.02.2021 


\section{Introduction}

Headache is a common disorder among the reasons for admissions to the hospital in pediatric patients. Migraine is the most common cause of primary headaches (1). It is known that migraine-type headache is seen in $8 \%$ of the children and adolescents throughout their lives. Its high incidence cause a negative impact on the quality of life (Qol) of children and their families (2). Headache affects the Qol through impaired school and academic evolution, family and friend relations, emotional functioning $(2,3)$. The studies showed headache is associated with lower academic performance (4). A child or adolesant suffering from migraine is at risk of long-term suffering in terms of lower Qol and reduced physical, social, and academic functioning. Sleep is very important for health and Qol. And its known that the children or adolesants with primary headaches have more sleep disturbance than the healthy controls (5).

Insomnia and obstructive sleep apnea syndrome are among the leading sleeping problems in children as well as in adults. Among school-age children, 5\% had insomnia complaints such as difficulty in initiating, continuing the sleep, or waking up at night (6). It was reported that 20 to $30 \%$ of the children had trouble going to sleep and woke up at nights (7). Insomnia in children has an important social influence affecting all family members and the parent-child relationship (8). The relationship between sleep and migraine headache has long been known. As in the study of Aguggia et al. (9), migraine and other primary headaches lead to sleep disruption, insomnia, hypersomnia, and cause daytime sleepiness. On the other hand, sleep disorders may trigger headache attacks, as well. The effect of headache episodes on the stages of sleep strengthens the hypothesis that the hypothalamus has a role in the pathophysiology of primary headaches. The serotonergic system has a critical role in the sleep-headache relationship and is particularly related to sleep regulation and pain modulation (10).

In this study, it was hypothesized that children between the ages of 8 to 18 who were diagnosed with an acute migraine attack, have more sleep-related problems and inferior Qol when compared with a healthy children group at the same age.

\section{Materials and Methods}

The study was commenced at the outpatient clinic of a tertiary neurological and psychiatric referral center. Inclusion criteria of the patient group were; (1) Patients aged between 8 to 18 , (2) Diagnosis of migraine without aura according to the International Classification of Headache Disorders 2013 guideline, (3) No other systemic, psychiatric or neurological disorders, (4) Not being under a migraine prevention treatment modality and receiving only attack treatment. The control group was formed out of volunteers responding to a call for the study. Inclusion criteria of the control group were; (1) Volunteers aged between 8 to 18, (2) No previous headache episode, (3) Not diagnosed with any neurological, physiatric, or systemic chronic disease. "The children's sleep habits questionnaire" (CSHQ) and "pediatric quality of life inventory-parent-form (PedsQL)" were administered to the parents of the volunteers or patients during admission or follow-up $(11,12)$.

The children's sleep habits questionairre (CSHQ) which consisted of 33 questions was developed by Owens et al. (13) in 2000. The questionnaire was translated to Turkish by Sezgin (11) in their dissertation on "sleep disorders in children with idiopathic generalized epilepsy" in 2002. In this questionnaire, a five-point rating scale was used (1=never, $2=$ only a few times, 3=sometimes, 4=often, and 5=always). Six questions were related to sleeping time difficulties and 5 questions were to sleep disruption. Parent-child overnight interaction was evaluated with 4 questions, parasomnia with 7 questions, and daytime sleepiness with 5 questions. In this study, questions with open ended answers (Q12, Q21, Q23 and Q24) were not included in analysis.

"Parent-form for subjects between the ages of 8-12" and "parent-form for subjects between the ages of 13-18" of the PedsQL were used in the patient and control groups. Varni et al. (14) confirmed the high internal consistency and validity of these inventories and Memik et al. (12) conducted the Turkish validity and reliability tests in 2005 . Physical functioning-related problems, emotional functioning-related problems, social functioning-related problems, and school-related problems were evaluated. The scale consisted of 4 subparts in which physical, emotional, social and school-related functioning were questioned. A five-point rating scale was used in the evaluation ( 0 =never, 1 =rarely, $2=$ =sometimes, $3=$ often, and $4=$ =always). Scores obtained from the questions were linearly converted to $0-100$ scale $(0=100,1=75,2=50,3=25$, and $4=0)$. The physical health total score was calculated from the means of the physical functioning part. The psychosocial health total score was calculated from the means of emotional functioning-, social functioning- and school-related problems. The scale's subscores (emotional functioning score, social functioning score and school functioning score) were calculated from the mean scores of the relevant parts. And the total score was calculated from the average score of all questions. If more than $50 \%$ of the questions were left blank, the patient was excluded from the study.

This study was approved by the ethical committee of our hospital in 2011 (it is a thesis).

\section{Statistical Analysis}

Statistical analyses were performed by NCSS 2007 Statistical Software 2007 (NCSS LLC, Utah, USA). For data analysis, in addition to descriptive statistical methods (mean, standard deviation), independent t-test was used in the comparison of binary groups and chi-square test was used in the comparison of qualitative data. The results at the level of $p<0.05$ were accepted as significant.

\section{Results}

The study included 43 patients (15 males and 28 females) with migraines and 48 volunteers ( 25 males, and 23 females) without migraines. The mean age of the patient and control group were $13.814 \pm 2.78$ and $12.56 \pm 3.5$, respectively. No 
significant difference was observed between the mean age and gender distributions between groups $[p=0.064, p=0.099$ $\left(\chi^{2}: 2,72\right)$, respectively]. All patients were diagnosed with episodic migraine. The mean frequency of headache episodes in the patient group was 2.3 (range, 1-5) attacks/month. No correlation was observed between scores of the patients their headache frequency.

\section{Qol Scale}

The sub-score distribution of the pediatric Qol inventory and the comparisons between groups were summarized in Table 1. Physical health total score, emotional functioning score, school functioning score, psychosocial health total score, and total scale score were significantly lower in the patient group $(p<0.05)$. No significant difference was observed between the social functioning scores of groups $(p=0.383)$ (Figure 1). No significant relationship was observed between age and physical health total score, emotional functioning score, school functioning score, psychosocial health total score, and total scale score $(p>0.05)$. No significant difference was observed between genders in terms of physical health total score, emotional functioning score, school functioning score, psychosocial health total score, and total scale score $(p>0.05)$.

\section{The CSHQ}

In this questionnaire, bedtime difficulties, sleep disruption, parasomnias, parent-child interaction overnight and daytime

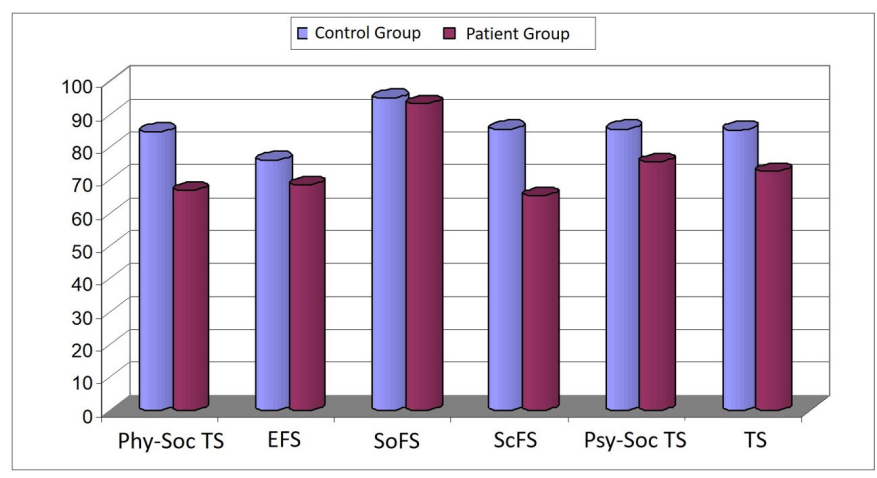

Figure 1. Comparing subgroup scores of pediatric quality of life inventory

Psy-Soc TS: Psychosocial health total score, EFS: Emotional functioning score, SoFS: Social functioning score, ScFS: School functioning score, TS: Total score sleepiness were evaluated (Table 2). No significant difference was found between patient and control groups in any subgroup (Figure 2).

A significant negative correlation was found between the age and the scores of overnight parent-child interaction $(r=0.337, p=0.027)$. No significant relationship was found between the age and sleeping time difficulties, sleep disruption, parasomnias, and daytime sleepiness $(p>0.05)$. There were no significant gender differences in terms of overnight parent-child interaction, bedtime difficulties, sleep disruption, parasomnias, and daytime sleepiness ( $p>0.05)$.

\section{Discussion}

In this study, Qol deterioration and sleep problems of children with migraines were investigated. Data obtained from these patients were compared with a group of healthy individuals of the same age and gender distribution. We have observed that children with migraines report lower Qol.

Headache is a common complaint in children and adolescents. Although headaches in children are mostly primary headaches such as migraine or tension-type headaches, other secondary causes such as central nervous system infections, disorders with increased intracranial pressure are encountered as well. Migraine is the most common primary headache in childhood. It negatively affects both patients and their families. In a study reporting results of 350 pediatric patients with headache, the most common primary headache was found to be migraine with a rate of $51.1 \%$ (15). The prevalence of migraine at school age was reported to range from $3.2 \%$ to

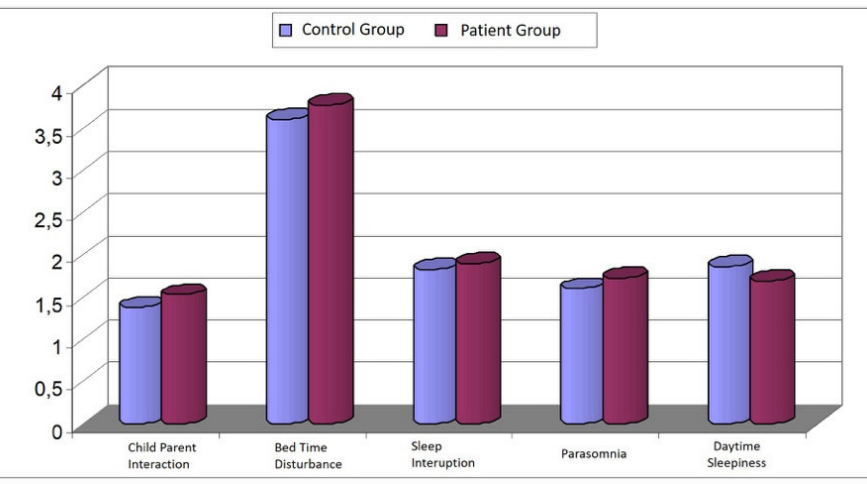

Figure 2. Comparing subgroup scores of children's sleep habits questionnaire

Table 1. The distributions of all the scores belonging PedsQL and the comparisons between the study group and control group

\begin{tabular}{|l|l|l|l|}
\hline PedsQL & Control group & Patient group & $\mathbf{p}$ \\
\hline Physical health total score & $84.7 \pm 12.22$ & $66.79 \pm 17.07$ & $\mathbf{0 . 0 0 0 1}$ \\
\hline Emotional functioning score & $76.08 \pm 14.89$ & $68.49 \pm 15.41$ & $\mathbf{0 . 0 1 9}$ \\
\hline Social functioning score & $95 \pm 7.72$ & $93.26 \pm 11.12$ & 0.383 \\
\hline School functioning score & $85.52 \pm 14.23$ & $65.12 \pm 18.24$ & $\mathbf{0 . 0 0 0 1}$ \\
\hline Psyhcosocial health total score & $85.53 \pm 9.24$ & $75.62 \pm 11.43$ & $\mathbf{0 . 0 0 0 1}$ \\
\hline Total score & $85.24 \pm 7.17$ & $72.55 \pm 12.06$ & $\mathbf{0 . 0 0 0 1}$ \\
\hline PedsQL: Pediatric quality of life inventory & & \\
\hline
\end{tabular}


Eren et al.

Sleep in Children with Migraine

\begin{tabular}{|c|c|c|c|}
\hline CSHQ & Control group & Patient group & $\mathbf{p}$ \\
\hline Parent-child interaction overnight & $1.38 \pm 0.61$ & $1.53 \pm 0.89$ & 0.333 \\
\hline Needs parents in room to sleep & $1.48 \pm 0.60$ & $1.63 \pm 1.113$ & 0.498 \\
\hline Move's to parents bed in night & $1.50 \pm 0.937$ & $1.65 \pm 0.997$ & 0.463 \\
\hline Sleeps at parents room & $1.13 \pm 0.619$ & $1.26 \pm 0.902$ & 0.444 \\
\hline Sleeps in parents bed & $1.24 \pm 0.705$ & $1.60 \pm 1.116$ & 0.066 \\
\hline Bed time difficulties & $3.61 \pm 0.73$ & $3.78 \pm 0.64$ & 0.258 \\
\hline Struggles at bedtime & $4.04 \pm 1.414$ & $3.92 \pm 1.324$ & 0.640 \\
\hline Falls asleep alone & $4.43 \pm 1.328$ & $4.58 \pm 1.139$ & 0.579 \\
\hline Falls asleep in own bed & $4.57 \pm 1.148$ & $4.47 \pm 1.260$ & 0.696 \\
\hline Falls asleep in parents bed & $1.52 \pm 0.863$ & $2.16 \pm 1.326$ & 0.008 \\
\hline Falls asleep in 20 minutes & $4.74 \pm 0.999$ & $4.44 \pm 1.402$ & 0.250 \\
\hline Sleep disruption & $1.83 \pm 0.43$ & $1.9 \pm 0.51$ & 0.442 \\
\hline Awakes once during night & $1.67 \pm 1.076$ & $2.30 \pm 1.206$ & 0.011 \\
\hline Awakes more than once & $1.04 \pm 0.295$ & $1.09 \pm 0.479$ & 0.555 \\
\hline No trouble sleeping away & $4.20 \pm 1.572$ & $3.52 \pm 1.798$ & 0.065 \\
\hline Trouble sleeping away & $1.13 \pm 0.653$ & $1.36 \pm 1.032$ & 0.217 \\
\hline Awake for eating & $1.04 \pm 0.206$ & $1.23 \pm 0.684$ & 0.077 \\
\hline Parosomnia & $1.6 \pm 0.57$ & $1.73 \pm 0.44$ & 0.248 \\
\hline Awakens sweating & $1.91 \pm 1.244$ & $2.32 \pm 1.350$ & 0.150 \\
\hline Sleep myoclonus & $1.63 \pm 1.062$ & $1.63 \pm 0.952$ & 0.991 \\
\hline Awakes confused & $1.22 \pm 0.629$ & $1.51 \pm 0.827$ & 0.061 \\
\hline Talks during sleep & $2.15 \pm 1.738$ & $2.16 \pm 1.111$ & 0.973 \\
\hline Sleepwalks & $1.26 \pm 0.743$ & $1.26 \pm 0.581$ & 0.972 \\
\hline Grinds teeth during sleep & $1.59 \pm 0.979$ & $1.79 \pm 1.116$ & 0.376 \\
\hline Awakes by screaming & $1.37 \pm 0.741$ & $1.44 \pm 0.825$ & 0.664 \\
\hline Daytime sleepines & $1.86 \pm 0.57$ & $1.69 \pm 0.51$ & 0.150 \\
\hline Wake up in negative mood & $3.67 \pm 1.446$ & $2.81 \pm 1.532$ & 0.008 \\
\hline Seems tired & $1.78 \pm 1.153$ & $1.42 \pm 0.96$ & 0.103 \\
\hline Watching TV & $1.57 \pm 1.003$ & $2.12 \pm 1.401$ & 0.035 \\
\hline Talking & $1.07 \pm 0.250$ & $1.09 \pm 0.294$ & 0.345 \\
\hline School & $1.09 \pm 0.463$ & $1.09 \pm 0.294$ & 0.942 \\
\hline \multicolumn{4}{|l|}{ CSHQ: The children's sleep habits questionnaire } \\
\hline
\end{tabular}

$14.5 \%$ in various studies (16-18). According to the study of Hershey et al. (19), headache causes several negative impacts on the life of both children and their families and negatively affect their Qol. Bruijn et al. (3) reported that pediatric patients had lower scores with the child health questionnaire. In another study, adolescents with primary headaches showed lower scores with KINDL-R questionnaire. The physical goodness score was particularly lower in patients with migraine and migraine plus tension-type headache. However, no decrease in mental, social, and school functions was observed (20).

In our study, a childhood health Qol scale, PedsQL, was utilized $(14,21)$. Patients with other types of primary and secondary headaches were not included in this study and a homogenous patient population was assessed. Similar to our study, Powers et al. (2) used PedsQL in the Qol evaluation in 686 children and adolescents with migraine. They reported lower scores in all sub-groups. In our study, we have observed similar social functioning scores between patient and control groups. Although this difference can be associated with parent-child communication, it is not possible to deduct a clear conclusion from this study. There are studies utilizing PedQL $4^{\text {th }}$ version to assess the Qol in children with migraine, which reported lower scores consistently with our study $(22,23)$.

In this study, we have also observed sleep problems of children with migraines. There is a complicated relationship between headache and sleep. It was reported that the association between sleep and pain has a two-sided relationship: Pain affects sleep quality, sleep quality affects pain (24). This complicated but strong relationship was noted in other studies as well $(25,26)$. In literature, there are several comparative 
studies showing that sleep disorders are more common in pediatric patients with migraine (27). Paiva et al. (28) reported that when underlying sleep disorders treated, headache also improved It was shown that new daily persistent headaches had a stronger association with sleep disorders compared to patients with migraine (18).

In this study, contrary to several studies in literature, no significant difference was found in the CSHQ values of the patient and control groups. Bruni et al. (29) reported no association of sleep disorders (sleep behaviors and sleep time) and migraine, but their questionnaires were administered to patients themselves, not caregivers. It is critical to administer childhood scores not only to patients but to families as well. The majority of the sleep problems are experienced by families, and not taken into attention by the children when questioned. Our CSHQ mean scores showed no gender and age association. A negative correlation was only found between PedQL score and age. From this result, it is possible to deduct that the children's need for their parents when initiating the sleep and during sleep decrease as the age increases. To our knowledge, there are no studies associating sleep disorders with age and gender in patients with migraine.

As a result of a study on 2.228 school-aged children, the prevalence of all sleep disorders was higher in patients with migraine (30). Snoring was commonly seen in patients with migraine. According to Miller et al. (31), 23\% of the children with migraine snore during sleep. Similarly with overall sleep problems, snoring alone also showed a two-way relationship with the headache. In a study on school-aged children between the ages of 11 and 15, the headache was commonly observed in children who often snored $(32,33)$. In our study, parents were questioned about snoring in the CSHQ part, but the results were not evaluated in scale scoring. We observed that $74.4 \%$ of the patient group and $75 \%$ of the control group had no snoring. This result suggests that there is no difference between the control and the patient groups with migraine.

There are studies suggesting that parasomnia is commonly seen in patients with migraine $(30,34)$. In a study, sleepwalking, sweating, and sleep terror was shown to be higher in children with migraine (33). In our study, no significant difference was found between the patient and control groups in terms of parasomnias, which is not consistent with the literature. This result may be associated with the sample size and lack of polysomnography. Studies with polysomnography report that sleep-apnea syndrome is common in patients with migraine (35).

\section{Study Limitations}

Limitations of the study are that the sample size was smaller than the compared literature and sleep disorders and moods of the patients were not evaluated with any scale. Polysomnography was not administered to the groups. The disorder duration and pain severity of the patients included in the study were not documented. Patients' migraine attacks were not documented using MIDAS scale. Therefore, it is not possible to make an assumption about the effect of the pain severity and duration of the disorder on the Qol and sleep. Although, age and gender distribution of both groups were statistically similar, there was a unsignificant trend towards female patients. It may have effect on our results related to gender discrepancies of migraine.

\section{Conclusion}

A decrease in the Qol except for social functioning score in children and adolescents with migraine between the ages of 8 and 18 was observed, which is consistent with the literature. These results reveal that the importance of the recognition of migraine is necessary to prevent and treat sleep disorders and increase the Qol. It is recommended for physicians and parents to be careful in terms of social problems. In future studies on this issue, enlarging the sampling and performing polysomnography on the patients will provide stronger deductions.

\section{Ethics}

Ethics Committee Approval: This study was approved by the Ethical Committee of İstanbul Bakırköy Prof. Dr. Mazhar Osman Mental Health and Neurological Diseases Training and Research Hospital in 2011 (date: 01.06.2011, number: 23852).

Informed Consent: Written informed consent was obtained from the parents of patients who participated in this study.

Peer-review: Internally peer-reviewed.

\section{Authorship Contributions}

Concept: F.E., G.G., H.Y., D.K., Design: F.E., G.G., H.Y., D.K., Data Collection or Processing: F.E., G.G., H.Y., Analysis or Interpretation: F.E., G.G., Literature Search: F.E., Writing: F.E., G.G., H.Y.

Conflict of Interest: No conflict of interest was declared by the authors.

Financial Disclosure: The authors declared that this study received no financial support.

\section{References}

1. Alehan F. Çocukluk Çağı Başağrılarının Prospektif Değerlendirilmesi. Çocuk Sağlığı ve Hastalıkları Dergisi 2003;46:38-42.

2. Powers SW, Patton SR, Hommel KA, Hershey AD. Quality of life in paediatric migraine: characterization of age-related effects using PedsQL 4.0. Cephalalgia 2004;24:120-7.

3. Bruijn J, Arts WF, Duivenvoorden H, Dijkstra N, Raat H, Passchier J. Quality of life in children with primary headache in a general hospital. Cephalalgia 2009;29:624-30.

4. Rocha-Filho PA, Santos PV. Headaches, quality of life, and academic performance in schoolchildren and adolescents. Headache 2014; 54:1194-202.

5. Klausen SH, Ronde G, Tornoe B, Bjerregaard L. Nonpharmacological Interventions Addressing Pain, Sleep, and Quality of Life in Children and Adolescents with Primary Headache: A Systematic Review. J Pain Res 2019;12:3437-59.

6. Lehmkuhl G, Fricke-Oerkermann L, Wiater A, Mitschke A. Sleep disorders in children beginning school: their causes and effects. Dtsch Arztebl Int 2008;105:809-14.

7. Sönmez M, editor Çocukluk Çağı ve Adolesan Döneminde Insomni. Ulusal Uyku Tıbbı Kongresi; 2008; Kuşadası: Türk Uyku Tıbbı Derneği

8. Thiedke CC. Sleep disorders and sleep problems in childhood. Am Fam Physician 2001;63:277-84. 
9. Aguggia M, Cavallini M, Divito N, Ferrero M, Lentini A, Montano V, Tinebra MC, Saracco MG, Valfrè W. Sleep and primary headaches. Neurol Sci 2011;32(Suppl 1):51-4.

10. Zurack N. Role of the suprachiasmatic nucleus in the pathogenesis of migraine attacks. Cephalalgia 1997;17:1701-5.

11. Sezgin I. İdiyopatik Jeneralize Epilepsili Çocuklarda Uyku Bozukluğu. Istanbul: Prof. Dr. Mazhar Osman Ruh ve Sinir Hastalıkları Eğitim ve Araştırma Hastanesi; 2002.

12. Memik N, Agaoglu B, Coşkun A, Üneri O, Karakaya I. Çocuklar Için Yaşam Kalitesi Ölçeğinin 13-18 Yaş Ergen Formunun Geçerlilik ve Güvenirliliği. Türk Psikiyatri Dergisi 2007;18:353-63.

13. Owens JA, Spirito A, McGuinn M. The Children's Sleep Habits Questionnaire (CSHQ): psychometric properties of a survey instrument for school-aged children. Sleep 2000;23:1043-51.

14. Varni JW, Seid M, Rode CA. The PedsQL: measurement model for the pediatric quality of life inventory. Med Care 1999;37:126-39.

15. Kılıç B. Evaluation of the Etiology, Clinical Presentation, Findings and Prophylaxis of Children with Headache. The Medical Bulletin of Sisli Etfal Hospital. 2019; [Ahead of print].

16. Abu-Arefeh I, Russell G. Prevalence of headache and migraine in schoolchildren. BMJ 1994;309:765-9.

17. Mortimer MJ, Kay J, Jaron A. Epidemiology of headache and childhood migraine in an urban general practice using Ad Hoc, Vahlquist and IHS criteria. Dev Med Child Neurol 1992;34:1095-101.

18. Birrer R, Fleisher I, Cortese L, Weiner M, Ferra I, Richards F, Plotz CM. An urban primary school health program. N Y State J Med 1991;91:339.

19. Hershey $A D$, Winner $P$, Kabbouche $M A$, Gladstein J, Yonker $M$, Lewis $D$, Pearlman E, Linder SL, Rothner AD, Powers SW. Use of the ICHD-II criteria in the diagnosis of pediatric migraine. Headache 2005;45:1288-97.

20. Milde-Busch A, Heinrich S, Thomas S. Quality of Life in Adolescents with Headache: Results from a Population based Survey. Cephalalgia 2009;30:713-21.

21. Üneri Öş, Şenbil N, Turgut S. Migrenli Ergenlerde Yaşam Kalitesi. Anadolu Psikiyatri Dergisi 2009;10:137-41.

22. Koller LS, Diesner SC, Voitl P. Quality of life in children and adolescents with migraine: an Austrian monocentric, cross-sectional questionnaire study. BMC Pediatr 2019;19:164.
23. Orr SL, Christie SN, Akiki S, McMillan HJ. Disability, Quality of Life, and Pain Coping in Pediatric Migraine: An Observational Study. J Child Neurol 2017;32:717-24.

24. Selekler HM, Şengün E, Altun N. Epizodik ve Kronik Migrenlilerde Uyku Kalitesi ve Depresyon. Nöropsikiyatri Arşivi 2010;47:196-200.

25. Rasmussen BK. Migraine and tension-type headache in a general population: precipitating factors, female hormones, sleep pattern and relation to lifestyle. Pain 1993;53:65-72.

26. Kelman L, Rains JC. Headache and sleep: examination of sleep patterns and complaints in a large clinical sample of migraineurs. Headache 2005;45:904-10.

27. Rabner J, Kaczynski KJ, Simons LE, LeBel A. Pediatric Headache and Sleep Disturbance: A Comparison of Diagnostic Groups. Headache 2018;58:217-28.

28. Paiva T, Farinha A, Martins A, Batista A, Guilleminault C. Chronic headaches and sleep disorders. Arch Intern Med 1997;157:1701-5.

29. Bruni O, Russo PM, Ferri R, Novelli L, Galli F, Guidetti V. Relationships between headache and sleep in a non-clinical population of children and adolescents. Sleep Med 2008;9:542-8.

30. Isik U, Ersu RH, Ay P, Save D, Arman AR, Karakoc F, Dagli E. Prevalence of headache and its association with sleep disorders in children. Pediatr Neurol 2007;36:146-51.

31. Miller VA, Palermo TM, Powers SW, Scher MS, Hershey AD. Migraine headaches and sleep disturbances in children. Headache 2003;43:362-8.

32. Torok K, Fatemi A, Werner I, Kerbl R, Schwarz B, Ipsiroglu OS. [Snoring as an sign of sleep disorders in 11- to 15-year-old school children--initial results of a Vienna epidemiologic study]. Wien Klin Wochenschr 2003; 115:860-6.

33. Bruni O, Fabrizi P, Ottaviano S, Cortesi F, Giannotti F, Guidetti V. Prevalence of sleep disorders in childhood and adolescence with headache: a case-control study. Cephalalgia 1997;17:492-8.

34. Archbold KH, Pituch KJ, Panahi P, Chervin RD. Symptoms of sleep disturbances among children at two general pediatric clinics. I Pediatr 2002;140:97-102.

35. Vendrame M, Kaleyias J, Valencia I, Legido A, Kothare SV. Polysomnographic findings in children with headaches. Pediatr Neurol 2008;39:6-11. 